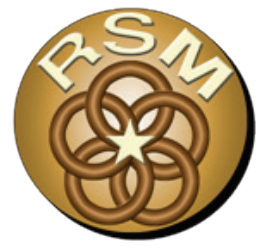

\title{
Pinellas, Manatee, and Sarasota Counties, Florida; Regional Sediment Budget
}

\author{
by Kelly R. Legault and Ashley E. Frey
}

PURPOSE: This U.S. Army Corps of Engineers (USACE) Regional Sediment Management Technical Note (RSM-TN) describes the regionalization of a sediment budget spanning three counties over 70 miles of coastline using two lidar surveys obtained by the USACE Joint Airborne Lidar Bathymetric Technical Center of Expertise. Volume change was determined between the first lidar survey during June 2006 and the second lidar survey during July 2010. The study area comprises the three counties of Pinellas, Manatee, and Sarasota, along the Gulf Coast shoreline of southwest Florida in the USACE Jacksonville District (SAJ) (Figure 1).

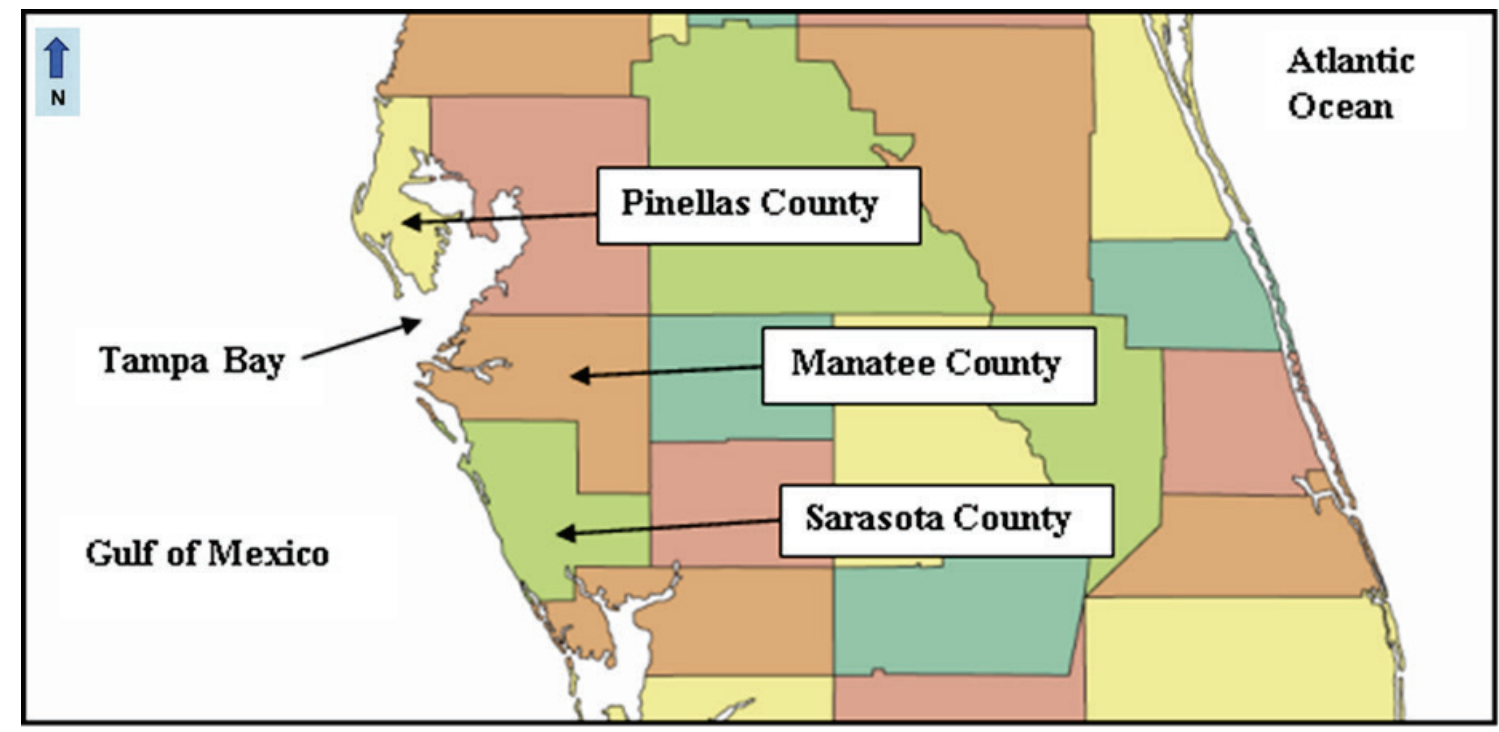

Figure 1. Study area comprising shorelines of Pinellas, Manatee, and Sarasota Counties, along southwest Florida Gulf of Mexico.

The region includes the entire shoreline from Clearwater Beach in Pinellas County to Venice Beach in Sarasota County, FL (Figure 2). Active projects in the study region include the Pinellas County Shore Protection Project (SPP) (USACE 2010), Tampa Harbor Navigation Project (deep draft), the Gulf Intracoastal Waterway (GIWW), Manatee County SPP at Anna Maria Island, the City of Sarasota SPP at Lido Key, Sarasota County SPP at Venice Beach, and a number of federally authorized navigation channels. Local projects exist as well at Longboat Key and at Siesta Key. This study was supported by the SAJ and the U.S. Army Engineer Research and Development Center through the USACE Regional Sediment Management (RSM) Program. 


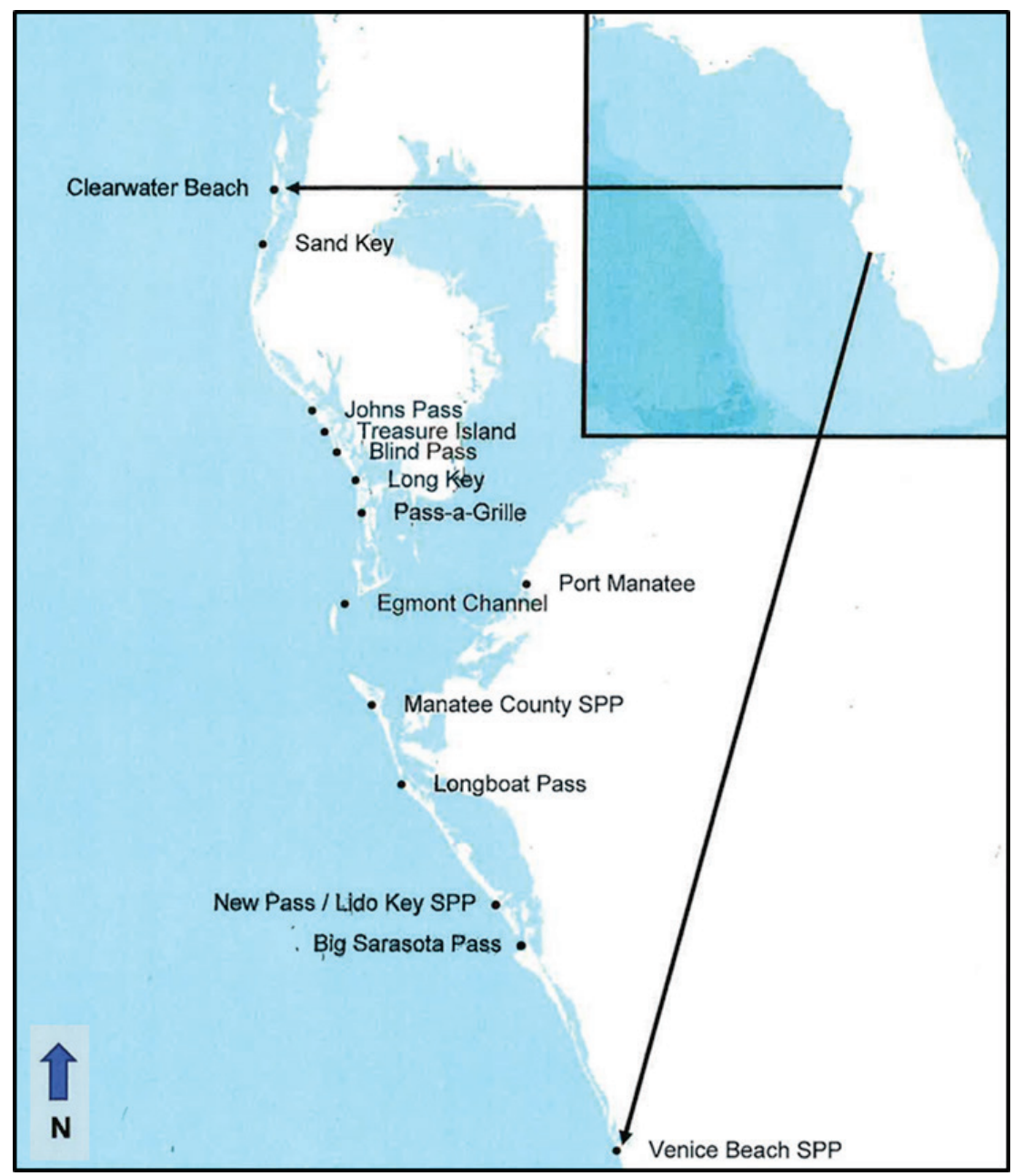

Figure 2. Sediment budget extent and active USACE Jacksonville District (SAJ) projects in Pinellas, Manatee, and Sarasota Counties, Florida.

INTRODUCTION: The southwest Gulf Coast of Florida consists of a barrier island system that has been under development since the early 1900s. At present, most of the shoreline is considered to be urban. It is directly under the influence of past and present anthropogenic activities including dredging of the passes that connect the Gulf of Mexico to back bays including Boca Ciega, Tampa Bay, and Sarasota Bay, as well as dredging of the GIWW. Additionally, placement of material from the passes and from offshore sources onto the beach has been in practice for well over 50 years. As a result of the severe hurricane seasons of 2004 and 2005, most of the beaches in Pinellas, Manatee, and Sarasota Counties were nourished from 2005 to 2009. Several sediment budgets have been developed for Pinellas County (Roberts 2012) and for Manatee and Sarasota Counties (Coastal Planning \& Engineering [now CBI Industries, Inc.] 2011; Coastal Technology Corporation et al. 2010). It was the objective of this study to create a sediment budget for the entire 70-mile region of shoreline from synoptic lidar measurements. Treatment of the lidar data is described by Legault (2016a). The entire extent of this new sediment budget is shown in Figure 2. The timeline for all federal project and data measurements is shown in Figure 3. 


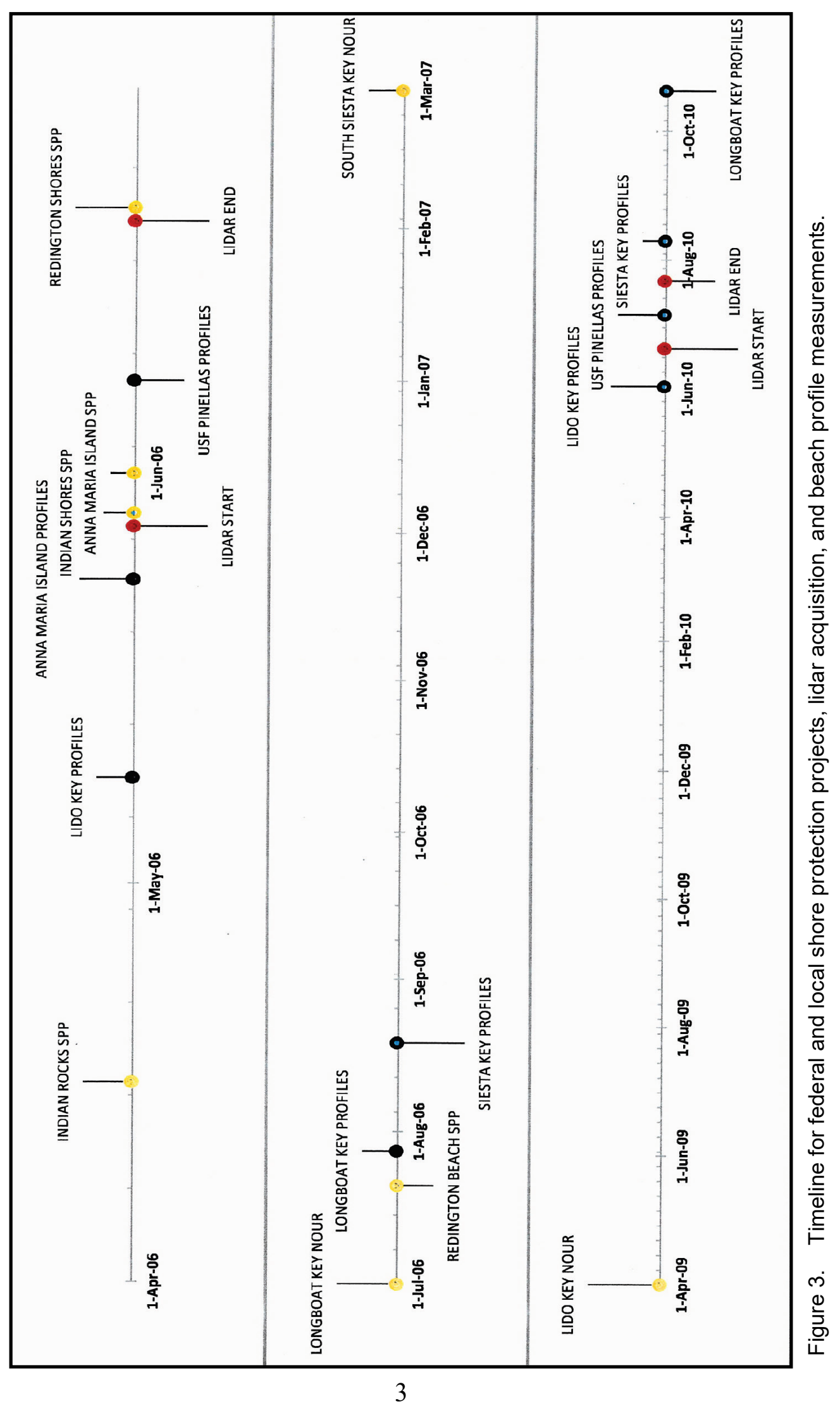


METHOD: The region of shoreline spanning Pinellas, Manatee, and Sarasota Counties includes several federal and local projects to improve navigation and to provide storm damage reduction along the shoreline beaches. The accounting and disparate analyses of such a number of projects warranted an RSM approach to determine the best sediment management practices and to examine the system holistically. The unprecedented hurricane season of 2004 and 2005, and the ensuing engineering projects spanning from 2005 to 2009, brought about a fundamental need to update the sediment budget for the entire region for the post-hurricane epoch of 2006-2010 using synoptically acquired lidar data. Two lidar surveys acquired over the southwest Gulf Coast including Pinellas, Manatee, and Sarasota Counties were analyzed to determine volume change over the 70-mile region between the first lidar survey of June 2006 and the second lidar survey of July 2010.

The treatment of the lidar data is explained by Legault (2016a). Results from the volumetric analysis were further analyzed using the Surface-water Modeling System (Aquaveo 2013) and Microsoft Excel. It was assumed that in Pinellas County a longshore sediment transport node (divergence zone) exists in the headland region of Indian Rocks and Indian Shores. This transport node has been well documented in previous studies (USACE 2010; Roberts 2012). The northern boundary was adjusted such that this divergence was reflected in the cumulative volume change calculations. Cumulative volume changes (spatially integrated changes) and changes in annual volume densities were calculated such that the former reveals spatial scales over which volume changes are balanced. The latter shows local changes in volume densities that are driven by a balance of anthropogenic activities, underlying morphology, and environmental forcing.

RESULTS: A total of 5.7 million cubic yards (Mcy) of material was placed in Pinellas, Manatee, and Sarasota Counties during the 2005-2009 reconstruction period, following the hurricane seasons of 2004 and 2005. Of the total, 3.9 Mcy were placed between the lidar surveys in June 2006 and July 2010 (Figure 3). This volume was removed from the volume change calculated and described by Legault (2016a). The divergent zone in Pinellas County, identified in previous studies and validated in resulting calculations by Legault (2016a), remains a fundamental feature in the littoral system that separates the littoral cells to the north and to the south. Resulting volume changes in cubic yards/year (cy/yr), cumulative volume changes (cy/yr), and volume density changes in cubic yards per foot of shoreline per year (cy/ft/yr) are shown in Figure $4 \mathrm{a}, 4 \mathrm{~b}$, and $4 \mathrm{c}$, respectively. The overall sediment budget is shown in Figure 5 and displays volume density changes along the shoreline.

The cumulative volume changes plot shows the alongshore location where the volume of sediment balances (Figure 4b). The first and most northerly location is that which was forced to be at the divergent zone at Indian Shores. Next, the volume is balanced at the north side of Johns Pass. The next location where volume is balanced is at the mouth of Tampa Bay. The region from Egmont Channel to mid-Longboat Key is the next alongshore reach where volume is conserved. The last few reaches are from mid-Longboat Key to the north side of New Pass, Lido Key, to the attachment point at Big Sarasota Pass, and from Siesta Key to the pier at Venice Beach. 


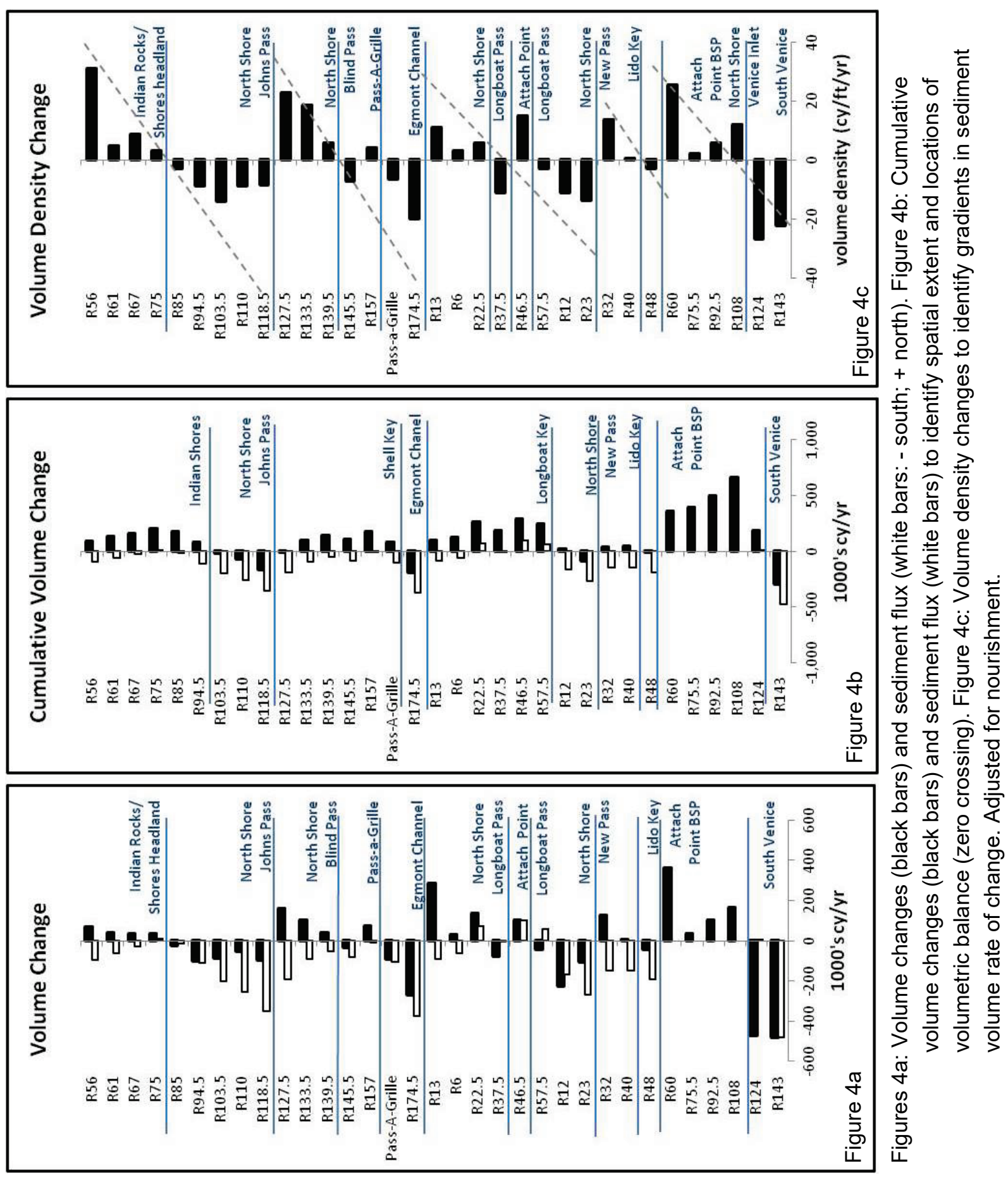




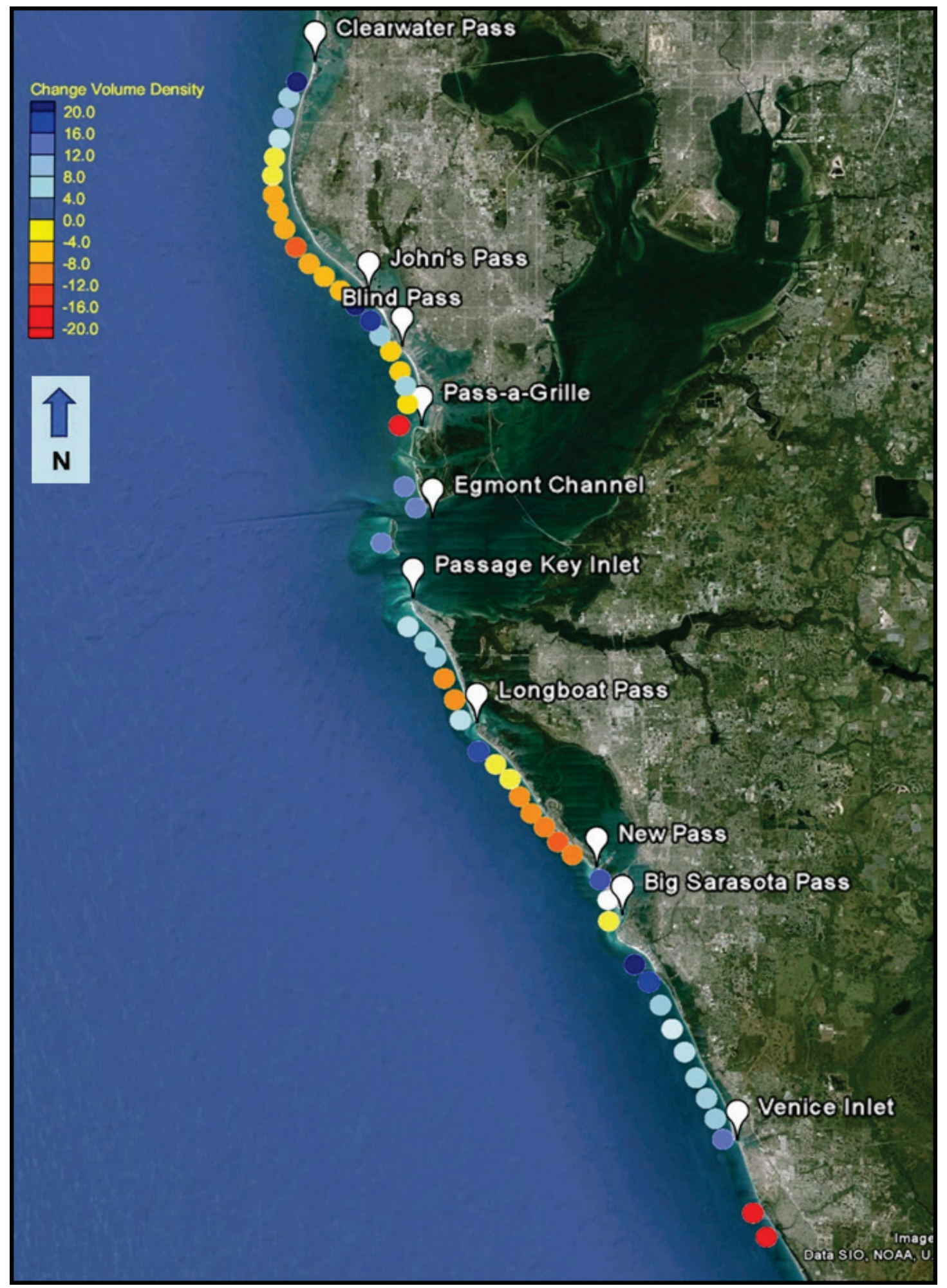

Figure 5. Southwest Florida Gulf Coast sediment budget volume density changes, adjusted for nourishment $+/$ - cy/yr/ft. Contour colors denote volume changes (cool colors $=$ erosion; warm colors = accretion). Developed using lidar. June 2006 - July 2010. 
The change in beach volume densities (Figure 4c and Figure 5) decreases from Clearwater Pass to the North Shore of Johns Pass, from the south shore of Johns Pass to Egmont Channel, from Egmont Key to the north shore of New Pass, from New Pass to Big Sarasota Pass, and from the attachment point of Big Sarasota Pass at Siesta Key to South Venice beach.

DISCUSSION: Lidar data give the best regional picture of the change in beach volume densities than through the use of beach profiles alone, that are used at the project scale. Along this stretch of shoreline in southwest Florida, it is clear that the greatest increase in volume densities is at the attachment point of many of the passes. Interestingly, as the cumulative volume changes would show, the reaches of shoreline that span inlets are the very ones that do not bypass sediment efficiently. For example, at Longboat Pass, there is very little southerly sediment flux at present, and sediment needs to be mechanically bypassed by dredging the navigation channel and placing sediment on the beaches at Longboat Key (Coastal Planning \& Engineering 2011; Legault 2016b). Similarly, at Blind Pass (a structured inlet), there is severe downdrift erosion at Upham Beach (Roberts 2012). At Venice Inlet (another structured inlet), the lack of bypassing creates the need for nourishment at Venice Beach. The remaining passes (Johns Pass, Egmont Channel, New Pass, and Big Sarasota Pass) all have robust attachment points that feed down-drift beaches.

The lidar data give an overview of the major features of the system. Whereas project scale beach surveys remain the standard for the determination of exact volume of sediment required for a particular engineering project, lidar data contain valuable details regarding underlying morphology and sediment transport features. Here, there is an obvious pattern of transport repeated along the shoreline that is dictated by the efficiency with which sediment is bypassed at the passes, and by the volume and location of the attachment point of the ebb shoals. Overall, the shoals and passes are very important and govern the sediment transport system. On the project scale that often does not contain information about the adjacent passes, the picture of sediment transport is incomplete. However, through the use of lidar data, the important sediment transport features within the system become readily apparent.

SEDIMENT BUDGET: A sediment budget based on the results shown in Figure 4 was developed in the Sediment Budget Analysis System (SBAS) (Rosati and Kraus 2001 [rev. 2003]). The latest version of SBAS is a Python toolbox, which is accessed through ArcCatalog within ArcGIS 10.1 or later. The sediment budget equation in SBAS is expressed as

$$
\sum Q_{\text {source }}-\sum Q_{\text {sink }}-\Delta V+P-R=\text { Residual }
$$

where $Q_{\text {source }}$ and $Q_{\text {sink }}$ represent all sources and sinks to/from the control volume (cell), $\Delta V$ is the volume change within a cell, $P$ is the volume of material placed within the cell, $R$ is the volume of material removed from the cell, and Residual is the degree to which a cell is balanced (Rosati and Kraus 2001 [rev. 2003]). If the Residual is 0, the cell is balanced. 
The sediment budget for Pinellas, Manatee, and Sarasota counties is shown in Figures 6, 7, and 8. Green cells represent volume gain while red represents volume loss. Figure 6a spans from R56 to R127.5, and Figure 6b includes cells R127.5 to R13. Figure 7a includes cells R13 to R57.5 while Figure 7b spans R57.5 to R60. Cells R60 to R143 are shown in Figure 8. Sediment budgets are meant to show all information for each cell, so unlike Figure 4, nourishment and dredging ( $P$ and R) are included. Therefore, volume changes for each cell are different than Figure 4 because nourishment and dredging are accounted for in the sediment budget equation. The shorelines of Pinellas County experienced a volume gain of approximately 287,000 cy/yr. Ten cells in Pinellas County recorded a gain while six cells had a volume loss. Nearly 500,000 cy/yr of sand was placed on the beaches of Pinellas County, so the increase in volume is due to nourishment. Only two cells in Manatee County had a volume loss. Manatee County beaches gained approximately $88,000 \mathrm{cy} / \mathrm{yr}$ of sand from 2006 to 2010. Sarasota County experienced a volume loss of approximately $100,000 \mathrm{cy} / \mathrm{yr}$; however, this is attributed to the two southernmost cells, which experienced a significant loss of volume. Many of the cells in Sarasota County had volume gains from beach nourishment activities.

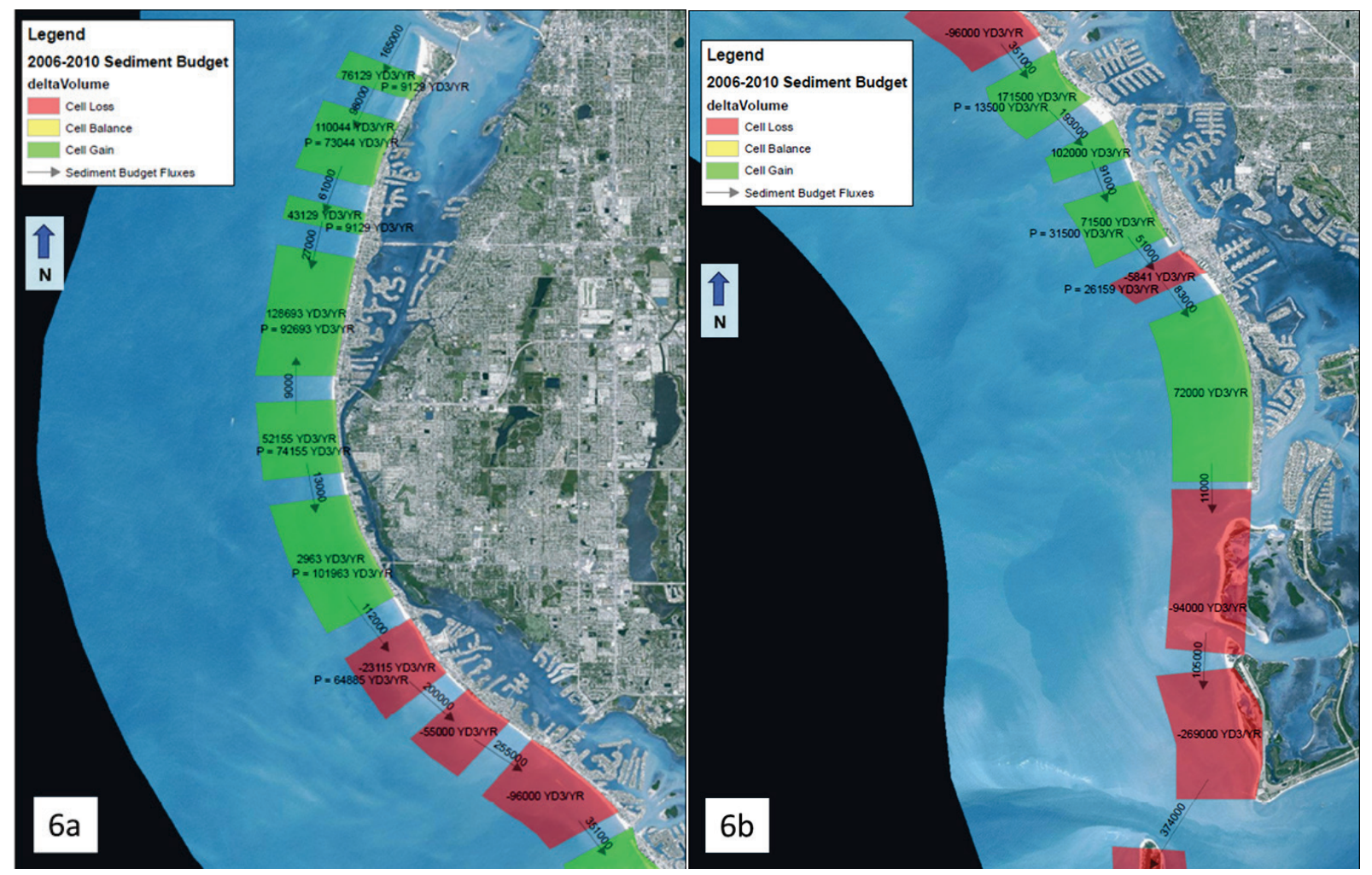

Figure 6a. Volume change in sediment budget cells representing R56 to R127.5; Figure 6b. Volume change in cells representing R127.5 to R13. P is Placement. 


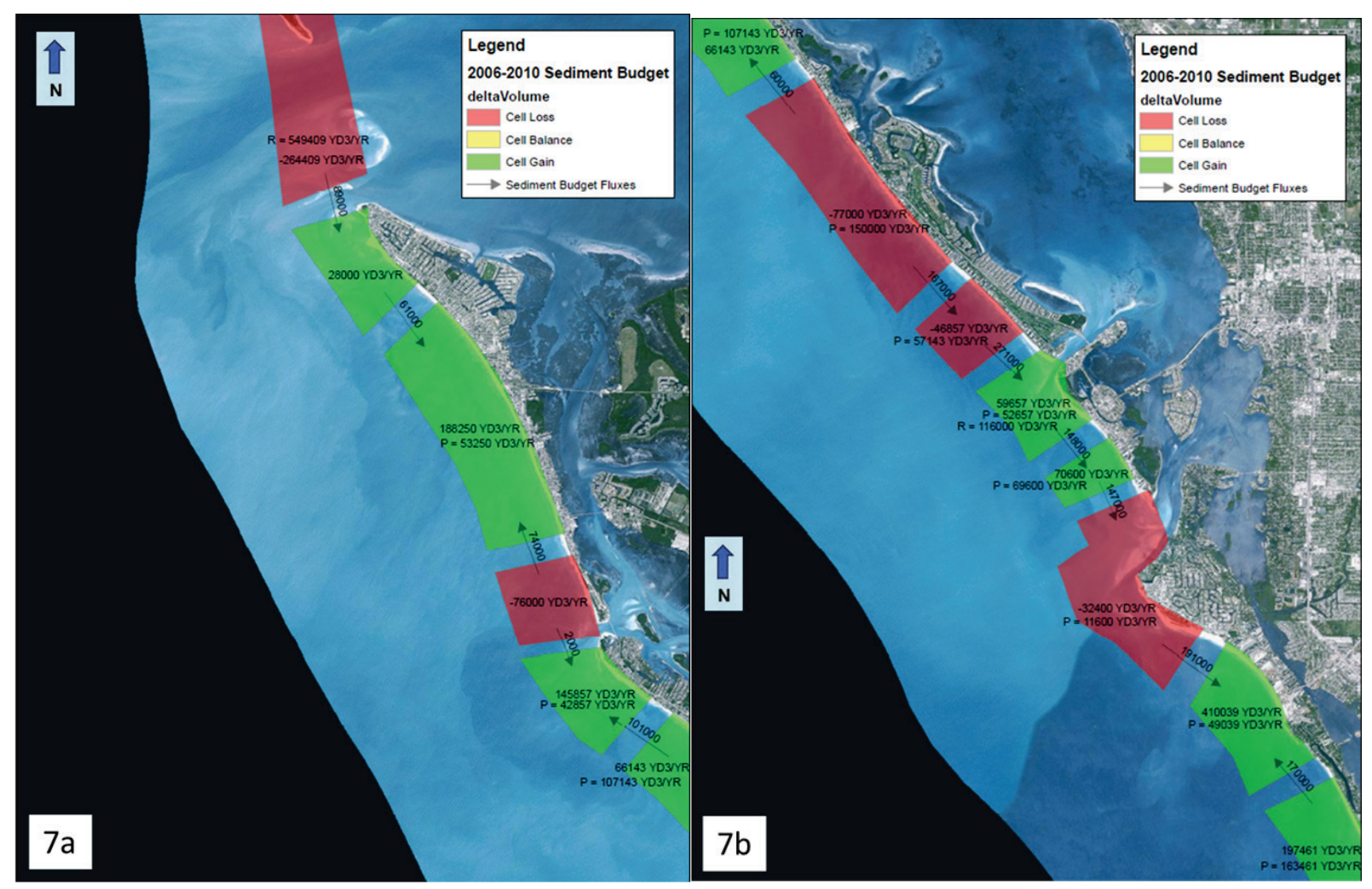

Figure 7a. Volume change in sediment budget cells representing R13 to 57.5 ; Figure $7 \mathrm{~b}$. Volume change in cells representing R57.5 to R60. P is Placement. $R$ is Removal. 


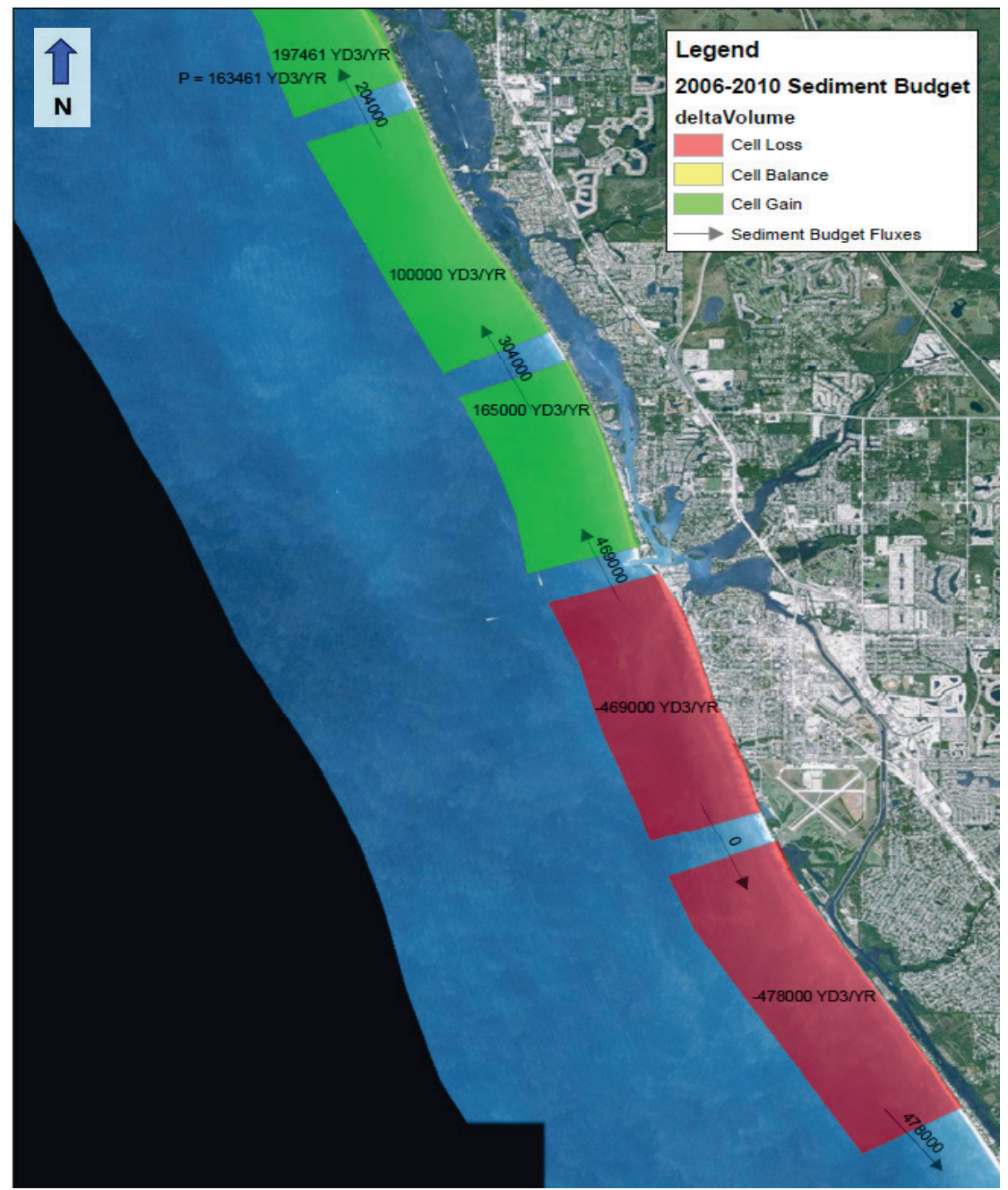

Figure 8. Volume change in sediment budget cells representing R60 to $R 143$. $P$ is Placement.

CONCLUSIONS: This RSM-TN documents the use of synoptic lidar data to develop a sediment budget along a 70-mile region of shoreline in southwest Florida. From this analysis, which gives an overview of the major features of the system, it is clear that the greatest increase in volume density is at the attachment point of many of the passes. Whereas project scale beach surveys remain the standard for the determination of the exact volume of sediment required for a project, far-reaching lidar data can offer a regional-scale view of the important sediment transport and morphologic features of the system at a scale that cannot be measured using beach profiles surveys alone.

ADDITIONAL INFORMATION: This USACE Regional Sediment Management Technical Note (RSM-TN) was prepared by Kelly R. Legault, U.S. Army Engineer District, Jacksonville (SAJ), and Ashley E. Frey, U.S. Army Engineer Research and Development Center (ERDC), Coastal and Hydraulics Laboratory (CHL). Funding for this study was provided by the USACE Regional 
Sediment Management (RSM) Program, a Navigation Research, Development, and Technology (RD\&T) Portfolio program administered by Headquarters USACE. Additional information pertaining to the RSM Program can be found at the RSM website http://rsm.usace.army.mil.

Questions regarding this RSM-TN may be addressed to Kelly $R$. Legault (Kelly.R.Legault@usace.army.mil), SAJ Senior Coastal Engineer, Engineering Division. Additional information pertaining to the RSM Program can be obtained from the USACE RSM Program Manager, Linda S. Lillycrop (Linda.S.Lillycrop@usace.army.mil)

This USACE Regional Sediment Management Technical Note (RSM-TN) should be cited as follows:

Legault, Kelly R., and Ashley E. Frey. 2017. Pinellas, Manatee, and Sarasota Counties, Florida; Regional Sediment Budget. ERDC/TN RSM-17-2. Vicksburg, MS: U.S. Army Engineer Research and Development Center. http://dx.doi.org/10.21079/11681/22907

\section{REFERENCES}

Aquaveo. 2013. Surface-water Modeling System (SMS). Version 12.2. http:/www.aquaveo.com/software/smssurface-water-modeling-system.

Coastal Planning \& Engineering, Inc. 2011. Inlet Management Study of Longboat Pass and Adjacent Beaches. Boca Raton, FL: Prepared for Manatee County and the Town of Longboat Key, FL.

Coastal Technology Corporation, Coastal Engineering Consultants, and Department of Geology/University of South Florida. 2010. Sarasota County Comprehensive Inlet Management Program; Big Pass and New Pass Management Alternatives. Prepared for Sarasota County, FL. Sarasota, FL: Coastal Technology Corporation. https://www.scgov.net/email/Lists/Submitted E-mail Records/Attachments/7219/2010-05-03 BigPass NewPass System.pdf.

Legault, K. R. 2016a. Beach and Morphology Change Using LIDAR. ERDC/CHL CHETN-XIV-54. Vicksburg, MS: U.S. Army Engineer Research and Development Center. http://hdl.handle.net/11681/20325.

Legault, K. R. 2016b. Regional Sediment Management (RSM) Assessment of Longboat Pass, Manatee County, FL. ERDC/CHL CHETN-XIV-49. Vicksburg, MS: U.S. Army Engineer Research and Development Center. http://hdl.handle.net/11681/20325.

Roberts, T. 2012. Natural and Anthropogenic Influences on the Morphodynamics of Sandy and Mixed Sand and Gravel Beaches. Graduate Thesis and Dissertation. Tampa, FL. University of South Florida. http://scholarcommons.usf.edu/etd/4216/.

Rosati, J. D., and N. C. Kraus. 2001 (rev. 2003). Sediment Budget Analysis System (SBAS): Upgrade for Regional Applications. ERDC/CHL CHETN-XIV-3. Vicksburg, MS: U.S. Army Engineer Research and Development Center. http://hdl.handle.net/11681/5013.

U.S. Army Corps of Engineers (USACE). 2010. Pinellas County, Florida Shore Protection Project: Long Key and Treasure Island Segments; 2006 Beach Nourishment. Third Annual Monitoring Report. Jacksonville, FL: U.S. Army Engineer District, Jacksonville.

NOTE: The contents of this technical note are not to be used for advertising, publication, or promotional purposes. Citation of trade names does not constitute an official endorsement or approval of the use of such products. 